Eskişehir Osmangazi Üniversitesi İlahiyat Fakültesi Dergisi Journal of Eskişehir Osmangazi University Faculty of Theology ISSN: 2147-8171

\title{
Hucurât Sûresinin 6. Âyeti Bağlamında Sosyal Medyadaki Gerçekdışı Haberler
}

\section{Unreal News on Social Media in the Context of Verse 6 of Surah Hujurat}

\section{Dr. Öğr. Üyesi İbrahim YILDIZ}

Mersin Üniversitesi, İslami İlimler Fakültesi, Tefsir Ana Bilim Dalı Mersin University, Faculty of Islamic Sciences, Department of Tafsîr, Mersin, Turkey.

i.yildiz@mersin.edu.tr

(iD) 0000-0003-0438-6994

Makale Bilgisi / Article Information

Makale Türü / Article Type Araştırma Makalesi / Research Article

Geliş Tarihi / Received Kabul Tarihi / Accepted Yayın Tarihi / Published

29 Mayıs / May $2021 \quad 13$ Eylül / September $2021 \quad 23$ Eylül / September 2021

\footnotetext{
Atıf Bilgisi / Cite as:

Yıldız, İbrahim. “Hucurât Sûresinin 6. Âyeti Bağlamında Sosyal Medyadaki Gerçekdışı Haberler”, Eskişehir Osmangazi Üniversitesi İlahiyat Fakültesi Dergisi 8/2 (Eylül 2021), 158-182.

http://doi.org/1051702/esoguifd.944505
}

İntihal / Plagiarism: Bu makale, en az iki hakem tarafından incelenmiş ve intihal içermediği teyit edilmiştir. / This article has been reviewed by least two referees and scanned via a plagiarism software.

Copyright @ Published by Eskişehir Osmangazi Üniversitesi, İlahiyat Fakültesi /Eskişehir Osmangazi University, Faculty of Theology Bütün hakları saklıdır. / All right reserved. https://dergipark.org.tr/tr/pub/esoguifd

CC BY-NC 4.0 This paper is licensed under a Creative Commons Attribution-NonCommercial License

Etik Beyanı / Ethical Statement: Bu çalışmanın hazırlanma sürecinde bilimsel ve etik ilkelere uyulduğu, yararlanılan tüm çalışmaların kaynakçada belirtildiği ve bu araştırmanın desteklenmesi için herhangi bir dış fon almadıkları yazar tarafından beyan olunur / It is declared by the author that scientific and ethical principles have been followed while carrying out and writing this study; that all the sources used have been properly cited; that no external funding was received in support of the research. 


\section{Hucurât Sûresinin 6. Âyeti Bağlamında Sosyal Medyadaki Gerçekdış1 Haberler}

Öz〉Günümüzde sosyal medya, kullanıcılarının iletişim ve haber alma ihtiyaçlarını önemli oranda karşılamaktadır. Fakat sosyal medyadaki sahte kullanıcı profillerinin varlığı, paylaşılan içeriklerin gerçek olup olmadığı konusunda şüpheler oluşturmaktadır. Hucurât sûresinin 6. âyetinde masum insanlara zarar vermemek için bir fâsığın getirdiği haberin iyice araştırılması emredilmektedir. Dinî ve ahlâkî durumları bilinmeyen sosyal medya kullanıcıları, doğrudan fâsık olarak nitelendirilemese de en azından bunların fâsık olma ihtimali bulunan meçhul kişiler oldukları kesindir. Bu nedenle onların aktardıkları haberler de ilgili âyetin kapsamına girmektedir. Müslümanların sosyal medya platformlarında gerçekdışı haberleri beğenerek, paylaşarak veya yorumlayarak masum insanların maddî veya manevî zarar görmelerine sebep olmaları, dinî açıdan sorumluluk gerektiren fiillerdendir. Bu çalışmada sosyal medya, sahte kullanıcı hesabı açma, gerçekdışı haber üretip yayma ve bunların dinî sorumluluğu konuları, Hucurât sûresinin 6. âyeti bağlamında derinlemesine araştırılmıştır. Çalışmamızda Kur’ân, tefsir, internet ve sosyal medya konularında literatür taraması metodu kullanılarak elde edilen veriler, sosyal medya platformlarının dijital ortamda incelenmesi ile desteklenmiştir.

Anahtar Kelimeler: Tefsir, Hucurât Sûresi, Sosyal Medya, Sahte Hesap, Fâsık, Manipülasyon.

\section{Unreal News on Social Media in the Context of Verse 6 of Surah Hujurat}

Abstract Today, social media significantly meets the communication and news needs of its users. However, the existence of fake user profiles in social media raises doubts about whether the shared content is real or not. In the 6th verse of the chapter of Hujurat, when a fasiq brings the news, it is ordered to investigate the news thoroughly in order not to harm people. Social media users whose religious and moral situations are unknown are not directly considered as a fasiq. However, it is certain that at least these people are anonymous people who are likely to a fasiq. For this reason, there is no doubt that the news they reported are also within the scope of the relevant verse. The fact that Muslims cause innocent people to suffer material and moral damage by liking, sharing or commenting on unreal news on social media platforms requires religious responsibility. In this study, social media, opening fake user accounts, producing, spreading false news and their religious responsibility were investigated in detail in the context of the 6th verse of the chapter of Hujurat. In our study, the data obtained by using the literature review method on the subjects of the Qur'an, commentary, internet and social media were supported by the digital examination of social media platforms.

Keywords: Commentary, Surah Hujurat, Social Media, Fake Account, Sinful, Manipulation.

\section{Giriş}

Günümüzde dijital teknolojinin hızla gelişmesi, hayatı adeta dijital platformlara taşımıştır. Müslümanlar da bu platformları kullanmakta ve zamanlarının önemli bir kısmını buralarda geçirmektedir. Sosyal medya olarak adlandırılan dijital ortamlar, bu platformların en çok kullanılanlarındandır. Sosyal medya, hayatın önemli bir parçası haline gelerek bireyin sanal ortamda diğer kullanıcılarla her an iletişim kurmasına, böylelikle sosyalleşmesine ve tüm dünyada meydana gelen olaylardan hızlıca haberdar olmasına imkân sağlamaktadır. Kullanıcılarının sadece 
Yıldız, Hucurât Sûresinin 6. Âyeti Bağlamında Sosyal Medyadaki Gerçekdışı Haberler

iletişim ihtiyacını değil oyun, eğlence ve bilgi edinme gibi ihtiyaçlarını da karşıladığından bu platformların üye sayıları hızla artmaktadır. ${ }^{1}$ Devlet başkanlarından, sıradan vatandaşlara kadar toplumun her kesiminin kullandığı sosyal medya, başta duygu ve düşünce olmak üzere her türlü iletiyi paylaşmaya, insanın kendisini ifade edebilmesi nedeniyle de mutlu ve faydalı hissetmesine olanak sağlamaktadır.

Sosyal medyanın yaygınlığı ve şöhreti, ona olan güveni de artırmış ve bu nedenle çoğu insanda sosyal medya aracılı̆̆ı ile ulaştığı bilgilere sorgulamadan güvenme eğilimi gelişmiştir. Bu eğilimin bir sonucu olarak kullanıcılar, rastladıkları her haberi, hızlıca beğenme ve paylaşma yoluna gitmektedirler. Fakat gerek şahısların gerekse toplumun ciddi zararlar görmesine neden olabilecek haberlerin güvenilir kaynaklardan teyit edilmeden diğer insanlara aktarılması ahlâkî, hukukî ve dinî sorumluluk doğurmaktadır. Gerçekdışı haberlerin kolayca üretilebildiği ve dolaşıma sokulabildiği sosyal medyada diğer insanlara zarar verecek iftira, yalan ve karalama içeren paylaşımlara bir müslümanın bilerek veya bilmeyerek destek vermesi, onların daha da yayılmasına sebep olması, aynen gündelik hayatta olduğu gibi sorumluluk gerektiren hususlardandır. Fakat çeşitli nedenlerden dolayı insanlar, dijital ortamlarda bu tür hassasiyetlere fazla dikkat etmemekte, günah veya mekruh sayılabilecek davranışları çok daha rahat sergileyebilmektedirler. ${ }^{2}$ Fakat sevap-günah, helal-haram mefhumları gerçek ortamlarda olduğu gibi sanal ortamlarda da aynen geçerlidir. Müslümanın, hayatın her anında imtihan edildiğine iman etmesi hasebiyle başta Yaratıcısına olmak üzere ailesine, akrabalarına, komşularına, çevresine velhâsıl tüm insanlara karşı sorumlulukları vardır ve bu hakikat, sanal ortamlarda da câridir. ${ }^{3}$

Bu çalışmada, sosyal medyada gerçekdışı haberlerin araştırılmadan beğenilmesi ve paylaşıma sokulması ile masum insanların maddî veya manevî zarar görmelerine sebep olacak eylemleri, Hucurât sûresinin "Ey iman edenler! Size bir fâsılk bir haber getirirse, bilmeyerek bir topluluğa zarar verip yaptı̆̆ınıza pişman olmamak için o haberin doğruluğunu araştırın.” meâlindeki 6. âyeti kapsamında incelenecektir. Daha önce yapılmış internet ve sosyal medya içerikli bazı çalışmalarda ${ }^{4}$ konuya kısaca değinilmiş ise de ayrıntılı bir şekilde ele alan herhangi bir çalışmaya rastlanılmamıştır. Araştırmamızın bu çalışmalardan farkı, sosyal medyada gerçekdışı haberler üretilip yayılması

1 Sosyal medya platformlarının üye sayıları hakkında ayrıntılı bilgi için bk. Eda Deligöz, Sanal Dünya ve İnsan (İstanbul: KDY Yayıncılık, 2020), 186-218.

2 Ayrıntılı bilgi için bk. Mustafa Derviş Dereli, Sanala Veda -Sosyal Medya ve Dönüşen Dindarlı- (Ankara: Nobel Akademik Yayıncılık, 2020), 227-236.

3 Bahattin Akbaş, “Sanal Ortam ve Mahremiyet”, Diyanet Aylık Dergi 287 (2014), 48-50.

4 Örn. bk. M. Raşit Akpınar, "İslam Hukuku Açısından Sosyal Medya”, Süleyman Demirel Üniversitesi Sosyal Bilimler Enstitüsü Dergisi 28 (2017), 493-509; Mehmet Yusuf Yağır, “Günümüz Medyasının Hucurât Suresindeki Bazı Ahlaki İlkelere Göre Değerlendirilmesi”, Şarkiyat 10/2 (2018), 638-650; Kâşif Hamdi Okur, "Sosyal Medya ve Hak Bilinci”, Mahremiyet Bağlamında Sosyal Medya ve Aile, ed. Fatih Kurt (Ankara: Diyanet İşleri Başkanlığı Yayınları, 2020), 4552; Abdülaziz Kıranşal, Gençler İçin Sosyal Medya İlmihali (MGV Yayınları, 2020), 46-47. 
konusunu Hucurât suresinin 6. âyeti özelinde ele almamızdır. Öncelikle gerçekdışı haberlerin oluşturulması ve yayılması merkezli sosyal medyanın gündelik hayatımıza yansıyan olumsuz yönleri ele alınacak, devamında ilgili âyette geçen bazı kelimeler bağlamında bu olumsuz yönlere karşı müslümanın nasıl bir tutum sergilemesi gerektiği tespit edilmeye çalışılacaktır. Çalışmamızda Kur'ân, tefsir, internet ve sosyal medya konularında literatür taraması metodu kullanılarak elde edilen veriler, yine sosyal medya platformlarının dijital ortamlarda incelenmesi ile desteklenmiştir.

\section{Sosyal Medya ve Olumsuz Yönleri}

Sosyal medya, kullanıcıların çevrimiçi haber, fotoğraf, video, metin gibi içerikleri kolayca üretebildikleri, diğer kullanıcılarla hızlıca paylaşabildikleri ve böylelikle geniş kitlelere kolaylıkla ulaşabildikleri çevrimiçi platformlardır. ${ }^{5}$ İçerik oluşturma tamamen kullanıcı denetiminde olup katılım ve paylaşım, sosyal medyanın dayanak noktasını oluşturmaktadır. ${ }^{6}$ Sosyal medya düşünce, ilgi ve bilgi paylaşımına imkân sağlayarak kullanıcıları arasında karşılıklı etkileşim meydana getirir. ${ }^{7}$ Özellikle mobil cihazların kullanılmaya başlanılması ile birlikte artık bilgi ve haberlere zaman ve mekân kısıtlaması olmaksızın ulaşılabilmektedir. ${ }^{8}$ Bunun yanı sıra sosyal medya, herkesin kolaylıkla kullanabilmesi, bilgilerin her an değiştirilebilir ve yeniden düzenlenebilir olması, her türlü fikrin kendine yer bulması gibi nedenlerle zamanımızda geleneksel medyadan çok daha yaygın olarak kullanılmaktadır. ${ }^{9}$

Günümüz toplumları, bilgi toplumu olma yönünde baş döndürücü bir hızla yol almaktadır. Buna bağlı olarak internet, bilgisayar, tablet ve cep telefonu gibi bilgi edinme araçları, hayatın vazgeçilmez bir parçası olmuştur. Bu nedenle sosyal medya platformlarının kullanıcı sayıları hızla artmış, eğlenceden eğitime, işten yardımlaşmaya kadar pek çok alanı etkisi altına almıştır. 2016 yılında yapılan bir araştırmaya göre sosyal medya platformlarından Facebook'un kullanıcı sayısı, yaklaşık bir buçuk milyar iken 2018 yılı sonunda iki milyara ulaşmıştır. Aynı şekilde kısa sürede popülerlik kazanan İnstagram'ın kullanıcı sayısı, bir milyara ulaşmışıır. ${ }^{10} 2019$ TÜíK verilerine göre Türkiye'de yaklaşık 81 milyon cep telefonu, 77 milyon internet abonesi bulunmaktadır. Bu verilere göre ülkemizde neredeyse herkesin cep telefonunun ve internet erişiminin olduğunu söylemek

\footnotetext{
5 Mustafa Bostanc1, Sosyal Medya -Dün Bugün Yarın- (Konya: Palet Yayınları, 2019), 22.

6 Ali Murat Kırık, "Gelişen Web Teknolojileri ve Sosyal Medya Bağımlılığı”, Sosyalleșen Birey \& Sosyal Medya Araştırmaları-1, ed. Ali Büyükarslan - Ali Murat Kırık (Konya: Çizgi Kitabevi, 2013), 74-75.

7 İdil Sayımer, Sanal Ortamda Halkla İlişkiler (İstanbul: Beta Yayıncılık, 2008), 123.

8 Vahit Özdemir, "Yeni Medyada Etik Sorunsalı", Sosyal Medya ve Etkileri, ed. Halil Özcan Özdemir (Ankara: Gece Akademi, 2019), 64-65.

9 Fatma Belgü Dikeçligil, “Ailede Çözülme ve Sosyal Medya Etkisi”, Mahremiyet Bağlamında Sosyal Medya ve Aile, ed. Fatih Kurt (Ankara: DỉB Yayınları, 2020), 102.

10 Emrah Bolat - Yunus Macit, "Postmodern Şiddet: Siber Zorbalık”, Sosyal Medya ve Etkileri, ed. Halil Özcan Özdemir (Ankara: Gece Akademi, 2019), 9.
} 
Yıldız, Hucurât Sûresinin 6. Âyeti Bağlamında Sosyal Medyadaki Gerçekdışı Haberler

mümkün gözükmektedir. ${ }^{11}$ Hatta dijital dünyanın sunduğu imkânların her konuda insanları etkileyen ve yönlendiren birer araç halini aldığı modern dünyada gündemin artık toplum önderleri tarafından değil sosyal medya tarafından oluşturulmakta olduğu iddia edilmektedir. ${ }^{12}$ Günümüzde sosyal medya; büyümesi engellenemeyen, kimsenin reddedemeyeceği, gündemi belirleyen, alınan kararları etkileyen ve yönetimleri değiştirebilen bir güç haline gelmiştir. ${ }^{13}$

Sosyal medya kullanıcılarının temel hedefi, insanlarla iletişime geçmek veya etkilemek istedikleri hedef kitlenin dikkatini çekecek ve daha fazla etkileşim alacak içerikler yayınlamaktır. ${ }^{14}$ $\mathrm{Bu}$ hedefe ulaşabilmek için internette gereğinden fazla zaman geçirilmesi, neticede bu gibi etkinlikleri yaşamın odak noktası haline getirmektedir. Böyle durumlarda kişinin sosyal ilişkileri, diğer insanların internetteki tutumlarına bağlı olarak gelişir veya biter. ${ }^{15}$ Sosyal medya, içeriğindeki doğru ve gerçek iletilerin yanı sıra gerçekdışı paylaşımlar nedeniyle eleştirilse de erişim kolaylığı, ileti çeşitliliği, çekici ve eğlenceli özellikleriyle çok sayıda insan tarafından kullanılmaktadır. Sosyal medya, çoğunlukla maddî kazanç elde etme adına koşuşturan, bu sebeple manevî duyguları ve insan ilişkileri geri planda kalan modern insan için bir rahatlama alanı oluşturmakta ve bu insanlar, karar vermekten tepki göstermeye kadar her türlü durumda sosyal medyayı kendilerine referans almaktadırlar. ${ }^{16}$

\subsection{Sosyal Medyanın Zararları}

Günümüzde üretilen yeni teknikler ve araçlar, çoğu zaman işleri kolaylaştırırken bazen de kötü niyetli insanların elinde tehlikeli birer araca dönüşmektedir. Fakat insanlar, gündelik hayatlarını kolaylaştıran ve kendilerini eğlendiren bu teknolojik ürünleri yaşamlarından çıkaramamaktadırlar. İnternet, kullanıcılarına sağladığı kolaylıklar ve faydaların yanında, insanlara zarar verme niyetinde olan kişilere de çeşitli imkânlar sağlamaktadır. Bu zararlar, iletişim araçlarının kullanımında yaşanan hızlı artışla orantılı olarak yaygınlaşmakta ve toplumun büyük bir kesimi tarafından hissedilir hale gelmektedir.

İnternet, insanlara özgür bir biçimde diğer insanlarla fikir alışverişinde bulunabileceği ve edinilen bilgilerle yeni düşünceler inşa edebileceği ortamlar sunarken aynı zamanda kendi sorunlarını da üretmiştir. İnternet zorbalığı, gerçekdışı bilgi ve haberlerin üretilip paylaşıma

11 https://data.tuik.gov.tr/Search/Search?text=internet\%20abone (Erişim: 08.05.2021)

12 Sedat Cereci, Sosyal Medya -Çağlar, Ağlar, Bağlar- (İstanbul: Onto Yayınları, 2019), 72.

13 A. Selim Tuncer, “Sosyal Medyanın Gelişimi”, Sosyal Medya, ed. F. Zeynep Özata (Eskişehir: Anadolu Üniversitesi Yayınları, 2013), 15.

14 Bostanc1, Sosyal Medya, 50.

15 Nevzat Tarhan - Serdar Nurmedov, Bağımlılı Sanal veya Gerçek Bağımlılıkla Başa Çıkma (İstanbul: Timaş Yayınları, 2020), 70.

16 Cereci, Sosyal Medya, 8, 16-18. 
sokulması, kurgulanmış haberin gerçekmiş gibi gösterilmesi, kutuplaştırıcı kötülüğün yaygınlaşması ve nihayetinde trollerin varlığı, başta sosyal medya olmak üzere çevrimiçi platformların güvenilirliğinin sorgulanması gerektiğini ortaya koymaktadır. ${ }^{17}$ Sosyal medya paylaşımlarına gerçek olup olmadığı araştırılmaksızın hemen inanılması ve diğer kullanıcılarla anında paylaşılması sorunu, bu sorgulamanın mutlaka yapılması gerektiğine işaret etmektedir.

\subsection{Sosyal Medyada Sahte Hesap Sorunu}

Sosyal medyanın, kullanıcılarına gerçek kimlikleri dışında başka kimliklerle giriş yapmalarına izin vermesi, birçok sorunu beraberinde getirmektedir. Bu ortamlarda farklı kimlik yapılarına bürünen insanlarda sorumsuzca hareket etme ve kendine özgü bir coşkunluk hali meydana gelmekte, ${ }^{18}$ bu ise çeşitli bunalımlara ve kimlik karmaşasına sebebiyet vermektedir. ${ }^{19}$ Sosyal medyadaki ahlâk dışı kullanıcı davranışlarını inceleyen araştırmacılar, birçok davranışın yanı sıra kişilerin gerçek kimliklerini gizleyerek sahte profiller oluşturmalarını da ahlâk dışı davranışlar arasında saymaktadır. ${ }^{20}$

Sosyal medyanın kullanım nedenlerinden biri de bireyin kendini psikolojik olarak tatmin etmesine imkân sağlamasıdır. Gerçek hayattaki aile, okul, iş, arkadaş vb. ilişkilerinde başarılı olamayan veya istediği düzeyde tatmin sağlayamayan birey, sosyal medyada kendine ideal bir kimlik oluşturarak bu durumu dengelemeye çalışmaktadır. ${ }^{21}$ Birey, bir bakıma sanal bir gerçeklik olarak ifade edilebilecek olan bu tutumla yani yeni inşa ettiği sanal kimliği ile sahneye çımakta ve ortaya koyduğu bu kimlik doğrultusunda davranmaya çalışmaktadır. ${ }^{22}$ Bu nedenle araştırmacılar, sosyal medyanın insanları toplumdan soyutladığını, asosyalleştirdiğini belirtirken sosyal medyada kullanılan kimliklerin, hayâ duygusunu yok ettiğini ve insanları narsisizme sürüklediğini vurgulamaktadır. ${ }^{23}$

Sosyal medyada kişilerin daha serbest ve sorumsuzca hareket etmelerinde, muhataplarının yüz yüze bakılan bir kişi değil de sadece bir internet hesabı olmasının büyük etkisi vardır. Bu durum, sosyal medya kullanıcılarının davranışlarına ket vurmasını zorlaştırmakta ve onlara sahte bir

17 Ekmel Geçer, Sosyal Medya ve İletişim Psikolojisi (İzmir: DỉB Yayınları, 2020), 106.

18 Tarhan - Nurmedov, Bağımlllık, 70.

19 Burhan Demirdaş - Ali Emrah Kurtulan, “Sosyal Medyanın Toplumsal ve İş Ahlakı Üzerine Etkileri”, Sosyal Medya ve Etkileri, ed. Halil Özcan Özdemir (Ankara: Gece Akademi, 2019), 46.

20 Örn. bk. Korhan Mavnacıŏ̆lu, “İnternette Kullanıcıların Oluşturduğu ve Dağıttığı İçeriklerin Etik Açıdan İncelenmesi: Sosyal Medya Örnekleri”, Medya ve Etik Sempozyumu, ed. Mustafa Yağbasan (Medya ve Etik Sempozyumu, Elazı̆̆: Firat Üniversitesi İletişim Fakültesi, 2009), 64.

21 Mehmet Emin Babacan, Sosyal Medya ve Gençlik (İstanbul: Bir Yayıncılık, 2017), 86.

22 Babacan, Sosyal Medya ve Gençlik, 87.

23 Demirdaş - Kurtulan, "Sosyal Medyanın”, 44. 
Yıldız, Hucurât Sûresinin 6. Âyeti Bağlamında Sosyal Medyadaki Gerçekdışı Haberler

cesaret duygusu vermektedir. ${ }^{24}$ Toplum içinde düşünerek ve seçerek sergilenen davranışlar, internette başkaları tarafından yargılanma endişesinin azalması nedeniyle kaygısızca ve rahatlıkla ortaya konulabilmektedir. ${ }^{25}$ Ayrıca beden dilinin sosyal medyaya yansımaması nedeniyle kişi, duygularını daha rahat bir şekilde gizleyebilmektedir. Bu nedenle sosyal medyada gerçek kimliğini kullanmayarak bunun yerine farklı birçok sahte kullanıcı hesabı açan yüzbinlerce insan bulunmaktadır. ${ }^{26}$ Şüphesiz sadece bu sahte hesaplar değil; bazı gerçek kullanıcılar da sosyal medyada ahlâkî değerlerin ya da sosyal normların geçerli olmadığını düşünmekte, bu nedenle başkalarına karşı kırıcı olmakta, onları ötekileştirmekte, farklı düşünceleri düşmanlaştırmakta, suçlamakta ve rahatlıkla yalan söyleyebilmektedir. ${ }^{27}$ Sosyal medyada kişilerin olduklarından farklıymış gibi gözükmeye çalışması, önemli bir ahlâkî sorun olmakla birlikte bu kişilerin yalan haber paylaşımları insanlarda diğer insanlara karşı bir güven bunalımına sebep olmakta ve herkesin her konuda bilgi sahibiymişçesine fikrini beyan etmesi de önemli bir bilgi kirliliğine yol açmaktadır. ${ }^{28}$ Ayrıca bu hesapların gerçek kişiler tarafından oluşturulup oluşturulmadığı veya hangi amaçlarla oluşturulduğunun bilinememesi de konunun ne kadar manipüle edilmeye elverişli olduğunu ortaya koymaktadır. ${ }^{29}$

\subsection{Sosyal Medyada Gerçekdışı Haber}

Günümüzde sosyal medya içeriklerinin ne kadar gerçek olduğu meselesi önemli tartışmalara sebep olmaktadır. Yeni medya ve etik konusunu inceleyen bir çalışmada, sosyal medyanın da aralarında bulunduğu yeni medya platformlarının etik sorunları arasında; içeriğin gerçek kaynağının belirtilmemesi, üretilen içeriklerin doğruluğunun tespit edilmeden yayılması, aldatıcı etiketleme ve başlıklandırma gibi birçok sorun sayılmaktadı..$^{30}$ Sosyal medyada kullanılan bazı uygulamalarla videolar ve fotoğraflar üzerinde sınırsız değişiklikler yapılabilmektedir. ${ }^{31}$ Fakat bunların hepsi iyi niyetle ya da sanatsal kaygılarla yapılmamaktadır. Kötü niyetli ve bazen de yaptığ şeyin sonunun nereye varacağını bilmeyen kullanıcılar, ekleme veya çıkarımlar ile değiștirdikleri görüntülü ya da yazılı materyalleri daha çok etkileşim alma arzusuyla sosyal medyada paylaşmaktadır. Birçok kullanıcı gerçekdışı bu içeriklere inanmakta ve onlar da kendi takipçileriyle paylaşmaktadır. Böylece bireysel bir yalan, dakikalar içinde toplumsal bir yalana dönüşmekte,

24 Ali Ayten, Mutluluğun Peşinde (İstanbul: Çamlıca Yayınları, 2018), 83.

25 Kemal Sayar, “Sosyal Medyanın Acımasız Yüzü: Linç Kültürü”, https://www.trthaber.com/haber/yasam/sosyalmedyanin-acimasiz-yuzu-linc-kulturu-494173.html (Erişim Tarihi: 08.05.2021)

26 Geçer, Sosyal Medya, 95-96.

27 Geçer, Sosyal Medya, 96.

28 Akpınar, "İslam Hukuku Açısından Sosyal Medya", 497.

29 Özdemir, "Yeni Medyada", 70.

30 Günseli Bayraktutan - Mutlu Binark, Ayın Karanllk Yüzü: Yeni Medya ve Etik (İstanbul: Kalkedon Yayınları, 2013), 39.

31 Geçer, Sosyal Medya, 100. 
içeriğinin hassaslığına paralel önlenmesi zor bireysel veya toplumsal zararlara neden olabilmektedir.

Haberlerin daha çok tıklanması için özellikle başlıkların abartılarak verilmesi, gerçekdışı olayların kurgulanması, seslerin montajlanması, görüntü ve fotoğraflarla oynanması, sosyal medyada sıklıkla karşılaşılan manipülatif davranışlardır. ${ }^{32}$ Özellikle yapay zekâ uygulamaları yardımıyla orijinal videodaki yüzleri değiştirerek bir başka yüz fotoğrafını maske olarak videodaki kişiye ekleyebilen deepface teknolojisi, günümüzde sahte videolar yapma konusunda ulaşllan noktayı göstermesi açısından oldukça dikkat çekicidir. Gerçekdışı bu videoları tam anlamı ile tespit eden bir teknolojinin henüz olmamasının yanı sıra tespit edilip kamuoyu ile paylaşılıncaya kadar geçen süre içerisinde sahte haberin dijital platformlardaki yayılma hızı hesaba katıldığında deepface videolarının vahim sonuçlar doğuracağını tahmin etmek güç olmayacaktır. ${ }^{33}$

Sosyal medya, güncel haberleri takip etme ve bilgi edinmede önemli kaynaklardan biri olmasına karşın buradaki en büyük sorun haber kaynağının anonimsizliğidir (isimsizliğidir). Özellikle sahte hesaplarla oluşturulan gerçekdışı içerikleri tespit edecek kuruluşların eksikliği sosyal medya kullanıcılarını kirli ve yönlendirici bir alana maruz bırakmaktadır. ${ }^{34}$ Sosyal medya platformları kullanıcı türevli olması nedeniyle hem haberin hem de bilgi verenin doğruluğunun kontrol edilmesi oldukça zordur. ${ }^{35}$ İnternet, art niyetli kişilerce hazırlanan sitelerde kasıtlı verilen yanlış bilgiler nedeniyle adeta bilgi çöplüğüne dönmüş ve kullanıcıların bu kadar çok çeşitli bilgi arasında doğru bilgiyi ayırt etmeleri oldukça zorlaşmıştır. Neticede internet, her ne kadar bilgiye hızlı ulaşma imkânı verse de doğru bilgiye ulaşmanın zorluğu nedeniyle insanların doğru kararlar vermesine zannedildiği kadar yardımcı olamamaktadır. ${ }^{36}$

\section{Hucurât Sûresinin 6. Âyeti ve Gerçekdışı Haberler}

Hucurât sûresi, Kur'ân'da İslâmî edep ve ahlâkın önemli ilkelerinin topluca zikredildiği bir sûredir. Bu sûrede beş defa tekrarlanan "Ey iman edenler"37 hitabı ile Allah'a ve peygamberine karş1 saygılı olunması, fâsıkların getirdiği haberlerin araştırılması, insanların birbirlerini aşağılamaması ve zanla hareket edilmemesi gerektiği üzerinde durulmuştur. Son olarak "Ey insanlar" ${ }^{38}$ şeklindeki

32 Geçer, Sosyal Medya, 103.

33 Bostanc1, Sosyal Medya, 112-113; Ayrıca bk. Geçer, Sosyal Medya, 104-105.

34 Yakup Toktay - Ali Murat Kırık, "Sosyal Medyada Dezenformasyon, Manipülasyon ve Propaganda Etkisi: Zeytin Dalı Harekâtı Örneği”, Sosyal, Beşeri ve İdari Bilimler Alanında Akademik Çalışmalar-2, ed. Hasan Babacan (Ankara: Gece Kitaplı̆̆ı, 2020), 497-498.

35 Şerife Öztürk, "Sosyal Medyada Etik Sorunu”, Selçuk İletişim 9/1 (2015), 300; Kırık, “Gelişen Web Teknolojileri”, 77.

36 Mücahit Gültekin, Algı Yönetimi ve Manipülasyon -Kanmanın ve Kandırmanın Psikolojisi- (İstanbul: Pınar Yayınları, 2018), 67-69.

37 el-Hucurât 49/1, 2, 6, 11, 12.

38 el-Hucurât 49/13. 
Yıldız, Hucurât Sûresinin 6. Âyeti Bağlamında Sosyal Medyadaki Gerçekdışı Haberler

hitapla ırkların sadece tanışma vesilesi olduğu tüm insanlara hatırlatılmıştır. Müslümanlara "Ey iman edenler" şeklinde hitap edilerek gelecek olan emirlerin önemi ve bu emirlerin ihlâl edilmeyip aynen yerine getirilmesi, onların iman vasıfları ön plana çıkartılarak vurgulanmıştır. ${ }^{39}$

Sûrede toplumsal birçok sorunu kökünden çözecek olan dürüstlük, adalet, barış, karşılıklı saygı ve hoşgörü ilkelerinin yanı sıra huzur ve güven ortamını zedeleyecek olan yalan haberlerin araştırılmadan gündeme alınmaması hakkında uyarı yapılmıştır. i̇lgili âyet, toplumsal düzenin bozulmaması, gerçekdışı haberler nedeniyle aralarına nifak ve tefrika girmemesi için mü’minlere sabırlı olmalarını, aralarında gidip gelen haberlerin doğru olmasına dikkat etmelerini emrederek onları irşat etmektedir. ${ }^{40}$ Çünkü İslam toplumunun temellerine yönelik en büyük tehlike, müslümanları birbirine düşman edebilecek haberlere gerçek olup olmadığını araştırmadan güvenmek ve onlara dayanarak birbirlerinin aleyhinde kararlar almaktır. ${ }^{41}$ Hucurât sûresinin konu ile ilgili 6. âyeti şöyledir:

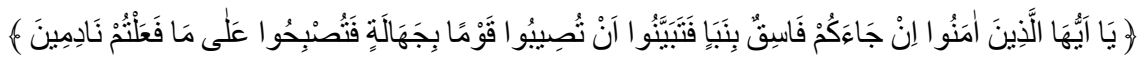

"Ey iman edenler! Size bir fâsık bir haber getirirse, bilmeyerek bir topluluğa zarar verip yaptığınıza pişman olmamak için o haberin doğruluğunu araştırın."

\section{1. Âyetin Nüzûl Sebebi}

Tefsirlerde bu âyetin nüzûl sebebi olarak şu olay nakledilir: Hz. Peygamber, Velîd b. Ukbe'yi Mustalikoğulları'nın zekâtlarını alması için gönderdi. Onlar, Hz. Peygamber'in elçisinin geldiğini duyunca onu karşılamaya çıtılar. Velîd, uzaktan onların şehirden çıktılarını görünce aralarındaki cahiliye döneminden kalma bir husumet nedeniyle kendisini öldürmek istediklerini zannetti ve korkarak geri döndü. Hz. Peygamber'e Mustalikoğulları'nın zekât vermeyi reddettiklerini üstelik kendini de öldürmek istediklerini anlattı. Bunun üzerine Hz. Peygamber onların üzerine askerî bir sefer düzenlemeyi düşündü. Bu arada Mustalikoğulları Hz. Peygamber'in kendilerine bir elçi gönderdiğini ama elçinin yoldan geri döndüğünü öğrenince bir heyet gönderip Hz. Peygamber'e zekâtlarını vermek için hazırlık yaptıklarını fakat elçinin geri döndüğünü söylediler. Resûlullah, Hâlid b. Velîd'i onlara göndererek gerçeği öğrendi ve olay, Hz. Peygamber'in teenni ile hareket etmesi ve araştırma yapması neticesinde hiç kimse zarar görmeden kapandı. ${ }^{42}$

39 Ebüssuûd Efendi, İrşâdü'l-akli's-selîm ilâ mezâya'l-Kitâbi'l-Kerîm (Beyrût: Dâru İhyâi't-Türâsi'l-Arabî, ts.), 8/115.

40 Abdullah Sirâcuddîn, Havle tefsîrü sûreti'l-Hucurât (Haleb: Mektebetü Dâri'l-Felâh, 1992), 67.

${ }^{41}$ Cüneyt Eren, "Hucurât Suresindeki Ahlâkî İlkeler”, Bozok Üniversitesi İlahiyat Fakültesi Dergisi 3/3 (2016), 1-20.

${ }^{42}$ Mukâtil b. Süleymân, et-Tefsîru'l-kebîr, thk. Abdullah Mahmûd Şehhâte (y.y.: Merkezu Tahkîki't-Türâs, 1979), 4/92-93; Ebû Ca'fer et-Taberî, Câmi'u'l-beyân an te'vîli âyi'l-Kur'ân, thk. Abdulmuhsîn et-Turkî (Kahire: Dâru Hicr, 2001), 21/350-352; Ebü'l-Hasen el-Mâverdî, en-Nüket ve'l-uyûn, thk. es-Seyyid Abdülmaksûd (Beyrût: Dâru'lKütübi'l-İlmiyye, ts.), 5/328-329; Ebü'l-Hasen el-Vâhidî, Esbâbü’n-nüzûl, thk. Kemal Besyûnî Zağlûl (Beyrût: Dâru'l- 
Nesefî̀ye (öl. 710/1310) göre müfessirler, bu âyetin Velîd b. Ukbe hakkında nâzil olduğu hususunda ittifak etmişlerdir. ${ }^{43}$ Fakat âyette geçen fâsık kelimesi ile Velîd b. Ukbe'nin kast edilip edilmediği konusu ihtilaflıdır. İmam Mâtürîdî (öl. 333/944), bu kişinin Velîd b. Ukbe olmadığ görüşündedir. Ona göre bu âyet, Velîd b. Ukbe'nin getirdiği haberden sonra nâzil olduğu ve haberin durumu iyice anlaşıldığı için artık o haberin doğruluğunu tekrardan araştırmak söz konusu değildir. Çünkü âyetin emri bundan sonra bir fâsığın getireceği haberin doğruluğunu araştırmayı emreder. Bu da âyetin Velîd b. Ukbe hakkında gelmediğini gösterir. ${ }^{44}$ Fahreddîn er-Râzîye (öl. 606/1209) göre de bu âyet, fâsığın sözüne itimat edilmeyip araştırılması gerektiğini beyan etmek üzere genel anlamda nâzil olmuştur. Ayrıca bu âyetin sadece bu olay hakkında nâzil olduğuna dair Kur'ân'da veya hadislerde bir açılama yoktur. Dolayısıyla bu olay bir bakıma âyetin iniş tarihini bildirmektedir. Râzînnin bu izahı, Velîd'e fâsık sıfatının verilmesinin de haksız ve geçersiz olduğunu açılamaktadır. Çünkü ona göre Velîd yanılmış, öyle sanmış ve sonuçta hata etmiştir. Hata edenlere ise fâsık denilemez. ${ }^{45}$

\section{2. Âyette Geçen Bazı Kelimeler ile Gerçekdışı Haberlerin Bağlantısı}

Bu bölümde Hucurât sûresinin 6. âyetinde geçen bazı kelimelerin lügat manaları açıklanacak ve müfessirlerin görüşleri, konuyla alakalı diğer âyetler göz önünde bulundurularak sosyal medyadaki gerçekdışı haberler bağlamında günümüze yansımaları incelenecektir. Yapacağımız yorum ve bağlantılar sadece sosyal medya haberleri kapsamında olacağı için âyetin ve içinde geçen kelimelerin ifade ve işaret ettiği diğer manalar, bu çalışmamız kapsamında ele alınmamıştır.

Kütüb'i-i̇lmiyye, 1991), 406-408; Fahreddîn er-Râzî, Mefâtîhu'l-gayb (Beyrût: Dâru'l-Fikr, 1981), 28/119; Ebû Abdullâh el-Kurtubî, el-Câmi'li-ahkâmi'l-Kur'ân, thk. Abdullah et-Türkî (Beyrût: Müessesetü'l-Risâle, 2006), 19/367368; Kâdî el-Beyzâvî, Envârü't-tenzîl ve esrârü't-te'vîl, thk. Subhî Hallâk - Mahmud Atraş (Beyrût: Dâru'r-Reşîd, 2000), 3/305-306; Ebü'l-Fidâ' İbn Kesîr, Tefsîrü'l-Kur'âni'l-'azîm, thk. Sâmi b. Muhammed es-Selîme (Riyad: Dâru Tayyibe, 1999), 7/370-372; Ebü'l-Fazl Celaleddin es-Süyûtî, Lübâbü'n-nukûl fi esbâbi'n-nuzûl (Beyrût: Müessesetü'lKütübi's-Sekâfiyye, 2002), 240; Sirâcuddîn, Havle, 67-68.

43 Ebü'l-Berekât en-Nesefî, Medârikü't-tenzîl ve hakâiku't-te'vîl, thk. Yusuf Ali Bedevî (Beyrût: Dâru'l-Kelimi't-Tayyib, 1998), 3/350.

44 Ebû Mansûr el-Mâtürîdî, Te’vîlâtü Ehli's-sünne, thk. Mecdi Ba Sellum (Beyrût: Dâru'l-Kütübi'l-ílmiyye, 2005), 9/326-327.

45 Râzî, Mefâtîhu'l-gayb, 28/119; Âyette zikredilen fâsığın kim olduğu hakkında yapılan tartışmalar ve her iki tarafın delilleri hakkında ayrıntılı bilgi için bk. Muhsin Demirci, Kur'ân Tefsirinde Farklı Yorumlar (İstanbul: İFAV Yayınları, 2017), 3/173-175. 
Yıldız, Hucurât Sûresinin 6. Âyeti Bağlamında Sosyal Medyadaki Gerçekdışı Haberler

\subsubsection{Fâsık (الفاست) Kavramı ve Sosyal Medyadaki Sahte Hesap İlişkisi}

F1sk, sözlükte "bir şeyin çıkması" demektir." Örneğin tohumun toprağı yarıp veya civcivin yumurtayı kırıp dışarı çıkması, konulan bir sınırın aşılması, bir yasağın çiğnenmesi gibi manalara gelir. Daha sonra büyük günahları işleyerek adaletten ayrılma manasındaki kullanımı yaygınlaşmıştır. ${ }^{47}$ Dinî örfte fisk, doğru yoldan saparak Allah'ın koyduğu emir ve yasaklara uymayıp itaatten çıkmaktır. ${ }^{48}$ Eğer bu çıkış itikâdî konularda olursa küfür; amelî konularda olursa isyandır. ${ }^{49}$ Kurtubî, fâsı̆̆ı "çok yalan söyleyen, açıktan günah işleyen veya Allah'tan utanmayan kimse" şeklinde açıklar. ${ }^{50}$ Bir kişi az veya çok günah işlediğinde fisk işlemiş sayılır fakat bu durum tövbe ile silinir. Ancak kişi iman ettikten sonra şeriatın bazı hükümlerini ihlâl eder, Allah'a ve Resûlü’ne itaat etmez ve dolayısıyla günah işlemekte 1 srar ederse artık ona fâsık adı verilir. ${ }^{51}$

Kur'ân genelde "fâsık" kelimesini inkârcı anlamında kullansa da fâsık, işlediği cürme göre ya bütünüyle dinden çıkarak küfre girmiş biri olabilir ya da dinle irtibatını kesmemiş günahkâr biri olabilir. Dolayısıyla bu âyeti anlamak için fâsık kelimesini her iki anlamı ile de ele almak gerekir. Yani dirayetli müslüman, bir fâssk haber getirdiğinde onu hemen reddetmemeli, bir müslüman özellikle şahsen tanınmayan- haber getirdiğinde de onu hemen kabul etmemelidir. Bilhassa gelen haber başka bir kişiyi/kişileri ilgilendiriyorsa daha da dikkatli olmak ve haberi mutlaka doğrulatmak gerekmektedir. Aksi halde o kişiye/kişilere sonrasında pişman olunacak haksızlıklar yapılabilir. ${ }^{52}$ Fâsık "dinin emirlerine uymayarak günah işleyen, doğruluk ve dürüstlük vasıflarını kaybeden kişi” olduğuna göre sosyal medyada yalan haber uyduran veya bu tür haberleri başkalarına taşıyan kimseler de bu kavrama dâhildir. Bu nedenle yalandan ve günahtan sakınmayan bir fâsığın getirdiği haberi araştırmayan bir müslüman, fıskın çeşitlerinden olan yalan, iftira ve zulümden de kendini koruyamaz. ${ }^{53}$

Âyetten çıkan genel hüküm, kim olduğu ve dinî hassasiyeti bilinmeyen veya günahtan çekinmeyen yalancı kimselerin verdikleri haberlere güvenilmemesi, bunlara dayanılarak hüküm

46 İsmâil b. Hammâd el-Cevherî, es-Sihâh, tah. Ahmed Abdulgafûr Attâr, (Beyrut: Dârü'l-ílm li'l-melâyîn, 1990), 4/1543; Râgıb el-i̇sfahânî, el-Müfredât fi garîbi'l-Kur'ân, thk. Muhammed Seyyid Keylânî (Beyrut: Dâru'l-Ma'rife, ts.), 380; Cemâleddin İbn Manzûr, Lisânü'l-Arab (Beyrut: Dâru Sâdır, ts.), 10/308.

47 Nesefî, Medârik, 3/351.

48 Halîlb. Ahmed el-Ferâhîdî, Kitâbü'l-Ayn-Müratteben alâ hurûfi'l-mu'cem-, thk. Abdülhamid Hendâvî (Beyrût: Dâru'lKütübi'l-İlmiyye, 2003), 3/321; Ebü'l-Abbâs Semîn el-Halebî, Umdetü'l-huffâz fî tefsîri eșrefil-elfâz, thk. Muhammed Bâsıl (Beyrût: Mektebetü Dâri'l-İlmiyye, 1996), 3/231.

49 Sirâcuddîn, Havle, 69.

50 Kurtubî, el-Câmi', 19/368.

51 el-İsfahânî, el-Müfredât, 380.

52 Mehmet Sait Şimşek, Hayat Kaynağı Kur'an Tefsiri (İstanbul: Beyan Yayınları, 2012), 5/30.

53 Ebü'l-Kâsım ez-Zemahşerî, el-Keşşâf an hakâ'ikı gavâmizi't-tenzîl ve uyûni'l-ekâvîl fî vücûhi't-te'vîl, thk. Halil Me'mun Şeyha (Beyrut: Dâru'l-Ma'rife, 2005), 1035; Nesefî, Medârik, 3/350. 
verilmemesi ve harekete geçilmemesidir. Âyetin bu yöndeki manası ve hükmü geneldir, her zaman ve mekânda geçerlidir. ${ }^{54}$ Sosyal medyada sahte hesapların yaygın olması ve kullanıcı hesaplarının kime ait olduğunun bilinememesi, oradan elde edilen bilgilerin güvenilirliği hakkında önemli şüpheler doğurmaktadır. Bu nedenle gerçek kimlikleri belli olmayan bu kişilerin ilettikleri haberler, İslâmî 1stılahla "meçhul kişinin rivayeti” kabilindendir. Cumhura göre mechûlü'l-ayn (tanınmayan râvi), adı sanı belli olmayan râvi hükmünde olup rivayeti kabul edilmez. ${ }^{55}$ İbn Kesîr'in (öl. 774/1372) tefsirinde belirttiği üzere bazı âlimler, günahkâr olma ihtimâlinden dolayı meçhul/tanınmayan kimselerin verdikleri haberlerin hemen kabul veya ret edilmemesi gerektiğini söylemişlerdir. ${ }^{56}$ Sosyal medya platformlarının kişilere sahte kullanıcı profili oluşturmalarına olanak sağlaması nedeniyle kullanıcıların büyük bir çoğunluğunun gerçek kimliklerinin net olarak bilinmesi imkânsızdır. Dolayısıyla bu kullanıcılar müslümanların nezdinde en azından "meçhul/tanınmayan kişi” hükmündedir. Bu durumda kimliğinden yüzde yüz emin olunmayan kullanıcıların fâsık olabileceği ihtimalinden hareket eden bir müslümanın, bu âyetin hükmü gereği karar verme konusunda sabırlı olması ve haberin gerçekliğini teyit etmek için araştırma yapması gerekmektedir.

Sosyal medyada bir haberin sürekli tekrarlanması insanlarda onun gerçek olarak algılanma ihtimalini güçlendirmektedir. Hedeflenen kitleye ve sonuca ulaşıldıktan sonra artık haberin gerçek olup olmadığının veya kaynağının güvenilir olup olmadığının bir önemi kalmamaktadır. Sosyal medyada kaynağı belli olmayan ve üzerinde dijital ortamda değişiklik yapılarak dolaşıma sürülen bir resim bu konuda örnek olarak verilebilir. Ailede kadına şiddet teması ile sosyal medyaya servis edilen ve Mehmet adındaki 5 yaşındaki bir çocuğun aile bireylerinden sadece babasını kolları olmadan çizdiği görülen bir resmin binlerce kez paylaşılmış ve üzerinde yorumlar yapılmıştır. Çocuğun annesini dövmemesi için babasını kolsuz çizdiğini söylemesi ise resmin mesaj veren açılkamasını oluşturmuştur. ${ }^{57}$ Fakat araştırmacılar bu resim, çocuk ve ailesi olayının ${ }^{58}$ tamamen bir kurgu olduğunu ispat etseler $\mathrm{de}^{59}$ binlerce kez paylaşılan ve yorumlanan resim, onu sosyal medyaya servis edenlerin amaçlarına yeterince hizmet etmiștir. Kaynağı belli olmayan ve aile bütünlüğüne, babanın aile içindeki saygınlığına saldıran bu paylaşımları, araştırmadan beğenen ve paylaşanlar da aile kurumuna saldıran meçhul/fâsık kişilerin bir bakıma oyununa alet oldukları açık bir gerçektir.

54 Hayrettin Karaman v.dğr., Kur'an Yolu Türkçe Meal ve Tefsir (Ankara: Diyanet İşleri Başkanlığ1, 2012), 5/89-90.

55 Emin Âşıkkutlu, “Meçhul”, Türkiye Diyanet Vakfi İslâm Ansiklopedisi (Ankara: TDV Yayınları, 2003), 28/287.

56 İbn Kesîr, Tefsîrü'l-Kur'âni'l-'azîm, 7/370.

57 Resmin paylaşıldığı ve yapılan yorumlarla ilgili sosyal medya paylaşım örnekleri için bk. https://m.facebook.com/psikolojivepsikiyatri/photos/a.425800540198/10152044439495199/?type=3\&p=30; https://twitter.com/omerekinci/status/404689628961071104. (Erişim Tarihi: 08.05.2021).

58 Resim, yabancı bir siteden alınmış ve üzerinde değişiklik yapılarak kullanılmıştır. Resmin aslı için bk. https://www.dreamstime.com/stock-images-kids-drawing-family-image19130844. (Erişim Tarihi: 08.05.2021).

59 Gültekin, Algı Yönetimi, 75-76. 
Yıldız, Hucurât Sûresinin 6. Âyeti Bağlamında Sosyal Medyadaki Gerçekdışı Haberler

Bir başka örnek ise Bursa'da Suriyeli bir sığınmacının bir kadına tecavüz edip onu öldürdüğü haberidir. Sosyal medyada hızla yayılan ve halk arasinda infiale neden olan bu haberin yalan, kullanılan fotoğrafların ise başka bir olaya ait olduğu resmi makamlarca açıklansa da çoğu sosyal medya kullanıcısı, doğruluğunu araştırmadan gerçekdışı bu haberin yayılmasına aracı olmuştur. ${ }^{60}$ Özellikle Suriyeli sığınmacılar hakkında yapılan bir araştırmada konunun bu yönüne dikkat çekilmiş ve sosyal medya üzerinden yapilan her türlü nefret söylemine engel olunması ve gerçekdışı bilgilerle halkı sığınmacılara karşı kışkırtan kişiler hakkında önlemler alınması istenmiştir. ${ }^{61}$ Aynı şekilde yalan haber olduğu sonradan ortaya çıkan fakat sosyal medya üzerinden binlerce kez paylaşılması nedeniyle halk arasında infiale yol açan onlarca örnek mevcut olup bunları paylaşanların büyük bir çoğunluğunun kimliği net değildir, meçhuldür dolayısıyla fâsık olma ihtimalleri vardır. ${ }^{62}$

\subsubsection{Nebe'(النبا ) Kelimesi ve Kaynağı Belli Olmayan Sosyal Medya Haberleri}

Haber manasında olan nebe' kelimesi, sadece büyük ve önemli haberler için kullanılır. ${ }^{63}$ İbn Kayyım (öl. 751/1350), nebe' kelimesinin "haber verilen kimsenin bilmediği önemli bir bilgi” için kullanıldığını kaydetmiştir. ${ }^{64}$ Âyette geçen fâsık ve nebe' kelimelerinin nekra olarak getirilmesi, "tüm fâsıkların getirdiği tüm haberler" şeklinde bir genellemeyi içermektedir. ${ }^{65}$ Adeta "Herhangi bir fâsık, size ne tür bir haberi getirirse getirsin onu araştırın" denilmek istenmiştir. ${ }^{66}$ Sosyal medyadaki kullanıcıların meçhul kişiler olmaları sebebiyle fâsık olabilecekleri ihtimali ve nebe' kelimesinin nekra olarak gelmesi, burada paylaşılan haberlerin mutlaka araştırılması gerektiğini

60 https://www.guvenliweb.org.tr/blog-detay/internet-ve-sosyal-medyada-yalan-haber-ve-sonuclari; https://www.bursadabugun.com/haber/bursa-da-sosyal-medyadaki-tecavuz-edilip-olduruldu-iddiasinasorusturma-869750.html (Erişim: 08.05.2021).

${ }^{61}$ Olgun Küçük - Mevlüt Can Koçak, "İnternet ve Sosyal Medya Haberlerinde Ötekinin (Suriyeli Sığınmacılar) Konumlandırılışı: Konya Örneği”, Journal of Humanities and Tourism Research 10/2 (2020), 282-287.

62 Sosyal medyada paylaşılan ve yalan olduğu tespit edilen bazı örnek haberlere ait web adresleri şöyledir: https://www.neokuyorum.org/linc-2-0-sosyal-medyada-linc-kulturu-kerem-gurel/; https://www.hurriyet.com.tr/yasasin-demokrasi/kafam-kesilmedi-ben-hayattayim-40163766; https://teyit.org/15-temmuz-darbe-girisimi-sirasinda-internette-yayilan-9-yanlis-iddia; https://medium.com/consensusturkiye/\%C3\%A7ift-tarafl\%C4\%B1-adalet-testeresi-sosyal-medya-1b48b85d21b. (Erişim: 08.05.2021).

63 Ferâhîdî, Kitâbü'l-Ayn, 4/179; Cevherî, es-Sihah, 1/74; İsfahânî, el-Müfredât, 481; İbn Manzûr, Lisânü'l-Arab, 1/162.

64 İbn Kayyım el-Cevziyye, Bedâi'ut-Tefsîr, thk. Seyyid Muhammed - Sâlih Ahmed (Riyad: Dâru İbn Cevzîyye, 1427), $3 / 6$.

65 Zemahşerî, el-Keşşâf, 1035; Beyzâvî, Envârü't-tenzîl, 3/306; Nesefî, Medârik, 3/350; İsmail Hakk1 Bursevî, Rûhu'lbeyân fì tefsîri'l-Kur'ân (ìstanbul: Matbaa-i Osmâniyye, 1911), 9/70.

${ }^{66}$ Zemahşerî, el-Keşşâf, 1035; Abdülmecîd el-Beyânûnî, el-Beyyinâtü fî tefsîri sûreti'l-Hucurât (Cidde: Dâru Nûri'lMektebât, 1997), 97. 
ihsas ettirmektedir. Çünkü bu iki kelimenin nekra olarak gelmesi her türlü haberi içine alacak şekilde bir geniş anlam alanı oluşturmaktadır.

Kur'ân, bilgisizce tartışmalara giren Ehl-i kitabı şöyle uyarmaktadır: "İşte siz böyle kimselersiniz! Diyelim ki biraz bilginiz olan şey hakkında tartıştınız. Ya hiç bilginiz olmayan şey hakkında niçin tartışıyorsunuz? Allah bilir, siz bilmezsiniz." ${ }^{67}$ Onların bildikler şeyler Tevrât ve İncil'in bildirdiği konular, bilmedikleri şeylerse kitaplarında olmayan Hz. İbrâhîm'in mensup olduğu din meselesidir. ${ }^{68}$ Âyet, bildikleri konular hakkında tartışmalarını normal karşılarken hiç bilmedikleri Hz. İbrâhîm'in hangi dine mensup olduğu konusunda tartışmalarını eleştirmektedir. Taberî (öl. 310/923), Katâde'den (öl. 117/735) bu âyet hakkında şu görüşü nakleder: "Âyette şahit olduğunuz, gördüğünüz ve tetkik ettiğiniz şeylerle görmediğiniz, şahit olmadığınız ve tetkik etmediğiniz şeyler kastedilmektedir." ${ }^{69}$ Dolayısıyla insanların, bilgi sahibi olmadıkları bir konuyu tartışmaları yasaklanmaktadır. ${ }^{70} \mathrm{Bu}$ bilgiler ışığında sosyal medyada paylaşılan haberlerin gerçek olup olmadığ hakkında kesin bilgisi olmayan kişilerin, konuyu tartışmaları dahi yasaklanmışken onu başkalarına nakletmeleri, yorum yaparak başka kişileri etkilemeleri evleviyetle yasaktır.

Kaynağı güvenilir ve belli olmayan her haber, zan hükmündedir. Bir şeyi sırf başkaları yapıyor diyerek bilgisizce taklit etmek de zanna tâbi olmaktır ki bu durum birçok âyette yasaklanmıştır. ${ }^{71}$ Fakat sınırlı düşünce ve algılama yetisine sahip insanın her konuda bilgi sahibi olması beklenemez. Ayrıca bilmediği tüm konuları araştırması da hem kapasite hem de zaman açısından mümkün değildir. Dolayısıyla zan kavramı, insanın otantik olarak benliğinde taşıdığı bir realitedir. ${ }^{72}$ Fakat bu, insanın bilmediği konularda zanna tâbi olmasını zorunlu kılmaz. İnsan, özellikle inanç konularında mutlaka vahye ve ona dayanan araştırma sonucu elde edeceği bilgiye tâbi olmak zorundadır. ${ }^{73}$ Çünkü kesin bilgiye ulaşmak için gayret göstermeyen insanda oluşan zanlar, temelsiz bilgilere dayandığı için onu yanıltabilir. ${ }^{74}$ Sosyal medyanın cazip ortamı ve birçok kişinin aynı paylaşımı yapması, bir müslümanı zannın peşinden giderek yanlış işler yapmasına neden olmamalıdır. Çünkü bilginin olmadığ yerde zan devreye girer, fakat zan genelde kişiyi yanlışa ve günaha götürebilir: "Ey iman edenler! Zannın birçoğundan sakının. Çünkü zannın bir kısmı günahtır..."75

\footnotetext{
67 Âl-i İmrân 3/66.

68 Mukâtil b. Süleymân, et-Tefsîru'l-kebîr, 1/283; Taberî, Câmi'u'l-beyân, 5/483-484; Zemahşerî, el-Keş̧̧âf, 176; Nesefî, Medârik, 1/263.

69 Taberî, Câmicu'l-beyân, 5/484.

70 Mâtürîdî, Te'vîlât, 2/395; Kurtubî, el-Câmi', 5/165.

71 el-En'âm 6/116, 148; Yûnus 10/36, 66; el-Hucurât 49/12; en-Necm 53/23, 28; Ayrica bk. Beyzâvî, Envârü’t-tenzîl, 2/301.

72 Muhammed Fatih Kesler, Kur'an-ı Kerim'e Göre Doğru Düşüncenin Engelleri (Ankara: Akçağ Yayınları, 2015), 25.

73 el-İsrâ 17/36; el-Hac 22/8; en-Necm 53/28.

74 İbrahim Yıldız, Kur'ân İnsan ve Yanılgı -Psikososyal Bir Okuma- (Bursa: Emin Yayınları, 2019), 240.

75 el-Hucurât 49/12.
} 
Yıldız, Hucurât Sûresinin 6. Âyeti Bağlamında Sosyal Medyadaki Gerçekdışı Haberler

Sosyal medyada paylaşılan haberleri de içine alacak şekilde anlam genişliği olan nebe' kelimesinin âyet içindeki anlamından anlaşılacağı üzere doğruluğundan emin olunmayan, sonuçları itibariyle kişiye/topluma zarar verme ihtimali olan bir haberin paylaşılması Allah katında önemsiz bir şey değildir. Iffk hadisesi hakkında nâzil olan âyetler de bu tespiti desteklemektedir. Hz. Âişe'ye (öl. 58/678) iftira atanlar ve bu iftirayı araştırmadan pervasızca toplumda yayanlar hakkında nâzil olan âyetler, ${ }^{76}$ müslümanların yalan haber karşısında takınmaları gereken tavrı göstermesi açısından son derece önemlidir. İfk hadisesi incelendiğinde ortada müslüman toplumun zaaflarını gözetleyen ve düşmanlık peşinde olan örgütlü bir grubun olduğu görülür. Bu grubun ortaya attığ 1 iftiraları toplumda yayanlar arasında bazı müslümanların da bulunması sosyal medyada dolaşan yalan haberlerin müslümanlar tarafından yayılmasına benzemektedir. Bu olay, bazı müslümanların farkında olmadan düşmanların tetikçiliğini yapabildiğini göstermektedir. ${ }^{77}$ Dolayısıyla sosyal medyada paylaşılan ve kişileri aşağılayan, suçlayan ve zarar veren haberler karşısında bir müslümanın tavrı şu âyette ifade edildiği gibi olmalıdır: "Bu iftirayı işittiğiniz zaman, iman eden erkek ve kadınlar, kendi (din kardeş)leri hakkında iyi zan besleyip de, 'Bu, apaçık bir iftiradır' deselerdi ya!"78

Sosyal medyanın yaygınlığı ve güçlü etkisi, kişilere güven telkin etmekte ve bu güven, paylaşımların sorgulanmasına engel olmaktadır. İște tam bu noktada Hucurât sûresindeki ilgili âyetin önemi ortaya çıkmaktadır. Özellikle hassas konularla ilgili paylaşımlar hakkında verilen haberin doğruluğunu araştırmak yani medya diliyle "farklı kaynaklardan doğrulatmak" gerekir. Bu nedenle âyet; hangi şartta ve durumda olursa olsun alınan haberin doğruluğunun israrla ve hassasiyetle araştırılması gerektiğini emretmektedir. Çünkü insan psikolojisi, kendi savunduğu düşünce, kurum ya da kişilerle ilgili her olumlu habere inanmaya, olumsuz haberleri ise göz ardı etmeye hatta baştan reddetmeye meyyaldir. Bu nedenle sosyal medyada özellikle sevmediği veya rakip olduğu kişilerle ilgili olumsuz haberler karşısında müslüman kullanıcıya düşen, âyetin emrettiği gibi konuyu her açıdan hassasiyetle araştırmaktır. Bu noktada sabırlı olmak ve paylaşma konusunda acele etmemek, belki de birkaç saat/gün içinde gerçek olup olmadığı ortaya çıkacak bir haber hakkında günaha girilmemesini sağlayacaktır. Çünkü acele ederek ve araştırmadan bu yalan bilgi ve belgelerin etrafa yayılmasına neden olunursa sadece bu yalanların muhatabı değil bizzat üreticisi ve yayıcısı konumuna düşülebilir. Her ne kadar böyle bir durumda sağduyulu hareket etmek, sosyal medyadaki gerçekdışı haberleri durdurmayacak olsa da en azından onların oluşturduğu tahribatı ve etkiyi en aza indirecektir. ${ }^{79}$

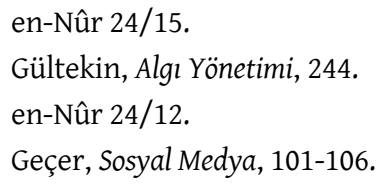




\subsubsection{Tebeyyün (تبين) Kelimesi ve Gerçekdışı Haberlerin Araştırılması}

Tebeyyün kelimesi, "maksudu keşfetmek, açıklamak" demektir. ${ }^{80} \mathrm{Bu}$ âyette ise "acele etmeyerek gelen haberin gerçek olup olmadığını araştırın ve durumu açılığa kavuşturun" manasındadır. İbn Kayyım, (تبينوا) kelimesinin "haberin bilgi açısından kuşatılması ve gerçek olup olmadığının araştırılması" anlamına geldiğini söyledikten sonra Allah'ın, fâsığın getirdiği haberin hemen reddedilmesini değil aksine onun gerçek olup olmadığının araştırılmasını emrettiğini, buna göre haberin doğruluğuna dair başka deliller varsa, o delillere göre davranılması gerektiğini söylemektedir. ${ }^{81}$ Âyetteki araştırma emri, haberi getirenin fâsık olması şartına bağlandığı için bu habere hemen güvenilmemesinin, bilhassa haberin gereğini yapma konusunda acele edilmemesinin önemine işaret etmektedir. Dolayısıyla sosyal medyada paylaşılan haberlerin kaynağını kesin olarak bilebilmenin adeta imkânsız olması nedeniyle bu paylaşımlara inanma ve başkalarına aktarma konusunda acele etmemek gerekir. Yüz yüze tanışılan kişilerin paylaşımları dahi olsa acele etmemekte fayda vardır çünkü sosyal medya hesaplarının zaman zaman çalınması nedeniyle art niyetli kişilerin eline geçtiği bilinen bir durumdur. Bu nedenle haberi aktaran kimsenin fâsık olup olmadığı bilinmiyorsa hatta mü'min, muttaki biri de olsa eğer getirdiği haber tuhaf, alışılmamış, moral bozucu, öfkeye veya bir hak kaybına neden olacak nitelikte ise yahut getiren kişiyle habere konu olanlar arasında bir düşmanlık varsa yine de acele edilmeyip araştırma yapılması tavsiye edilmiştir. ${ }^{82}$

Gelen haberlerin gereğini yapmadan önce iyice araştırmak, imanın bir gereğidir. Çünkü Allah, bu âyete "Ey iman edenler" şeklinde başlayarak mü'minlere Allah'ı, kitabını ve peygamberini tasdik ettiklerini hatırlatmaktadır. Dolayısıyla bu vasıflara sahip olan mü’min, doğruluğunu araştırmadığı bir haberden ötürü kardeşlerine zarar verebileceğini ve yapacağı şeylerden ötürü pişman olabileceğini, fakat sonuçta bu pişmanlığın bir kıymet ifade etmeyeceğini bilir. ${ }^{83}$ Bir haberi sağlam bir delil olmadan doğrulayıp kabul etmek gibi delilsiz olarak onu yalanlayıp reddetmek de uygun değildir. Bu nedenle toplumsal bir kargaşanın oluşmaması için mü’minlerin sosyal medyada araştırdıkları, doğruluğunu tespit ettikleri haberlerin peşinden gitmeleri ve kişilere zarar verecek, toplumun ifsadına sebep olacak paylaşımlardan sakınmaları gerekmektedir. Kuşkusuz burada söz konusu olan sosyal medya haberleri; kişileri veya grupları ilgilendiren, onlara zarar verebilecek

so İsfahânî, el-Müfredât, 68-69; Halebî, Umdetü'l-huffâz, 1/251.

81 Cevziyye, Bedâi'ut-Tefsîr, $3 / 6$.

82 Mustafa Adevî, et-Teshîl li te'vili't-tenzîl Tefsîru sûreti'l-Hucurât (Cidde: Dâru Mâcid Asîrî, 2000), 41-42; Mehmet Zeki Duman, Beş Surenin Tefsiri (Ankara: Fecr Yayınları, 1999), 298.

83 Muhammed Ali es-Sâbûnî, Ravâ'i'u'l-Beyân fî Tefsîri Âyâti'l-Ahkâm (Dımeşk: Mektebetu'l-Gazzâlî, 1980), $2 / 473$. 
Yıldız, Hucurât Sûresinin 6. Âyeti Bağlamında Sosyal Medyadaki Gerçekdışı Haberler

tarzdaki önemli haberlerdir. Yoksa normal günlük, sıradan haberler için haber getiren herkesin itikâdî ve amelî durumunu veya haberin doğru olup olmadığını araştırmak zorunlu değildir. ${ }^{84}$

İnsanın kendisine ulaşan birtakım haberlere dayanarak kararlar verip amel edebilmesi için onların üzerindeki zan perdesini kaldırması zorunludur. ${ }^{85}$ Çünkü İsrâ sûresinde "Hakkında kesin bilgi sahibi olmadığın şeyin peşine düşme. Çünkü kulak, göz ve kalp, bunların hepsi ondan sorumludur." ${ }^{\text {" } 6}$ buyurulmaktadır. Âyette geçen bu organlar, akıllı varlıklar gibi kabul edilerek yaptıkları amellerden sorumlu tutulmuşlar ve sâhibinin lehinde veya aleyhinde şâhit getirilmişlerdir. ${ }^{87}$ Mâverdî (öl. 450/1058), bu âyeti Abdullah b. Abbas'ın (öl. 68/687-88); "bilgin olmadığı bir konuda hiç kimse hakkında konuşma" şeklinde açıkladığını aktarmaktadır. ${ }^{88}$ Mücâhid (öl. 103/721), âyeti "hakkında bilgi sahibi olmadığın bir hususta hiç bir kimseyi yermeye kalkma"89 i̇bn Kuteybe (öl. 276/889) ise "zan ve tahminlerinin peşinden gitme" şeklinde izah etmiştir. ${ }^{90}$ Zemahşerî (öl. 538/1144), “Allah bu ayetle, kişiyi bilmediği bir konuda söz söylemekten ve bilmediği şeylerle amel etmekten sakındırmaktadır" demektedir. ${ }^{91}$ Tüm bu izahlar, sosyal medyada meçhul bir kullanıcının yazdığı ve doğru olup olmadığı bilinmeyen haberlere inanma ve onları paylaşma konusunda acele edilmemesinin, gerekli araştırma yapıldıktan sonra kesin karara varılmasının gereği hususunda mü'minlere yol göstermektedir.

\subsubsection{Nâdimîn (نادمين) Kelimesi ve Sosyal Medyada Pişmanlık}

Nedâmet, bir üzüntü çeşidi olup kişinin yaptığına/söylediğine pişman olarak üzülmesi demektir. ${ }^{92}$ Yapılan fiil veya söylenen söz her hatırlandığında üzüntü, pişmanlık yenilenir ve kişi devamlı surette vicdan azabı çeker. ${ }^{93}$ Özellikle iftira atılan ve töhmet altında bırakılan kişinin suçsuz olduğu ortaya çıktığında bu vicdan azabı daha da şiddetlenir. ${ }^{94}$ Araştırılmadan elde edilen bilgi, cahillikle eşdeğerdir. Bu tür bir bilgiye dayanarak masum bir kişiye zarar verenler, telafisi mümkün olmayan bir üzüntüye kapılırlar. Çünkü böyle bir haksızlık yapan mü’minin imanı, onun vicdan

84 Musa Kazım Yılmaz, "Hucurât Suresinin Öne Çıkardığı Âdâb-1 Muâşeret", Harran Üniversitesi İlahiyat Fakültesi Dergisi 38 (2017), 9.

85 el-Hucurât 49/12; Müslim, "Birr", 38.

86 el-İsrâ 17/36.

87 Beyzâvî, Envârü't-tenzîl, 2/302; İbrahim Yıldız, “Kur’ân'da Hesap Günü Şahitleri”, Diyanet İlmi Dergi 53/4 (2017), 69-71.

88 Mâverdî, en-Nüket, 3/243; Kurtubî, el-Câmi', 13/77.

89 Kurtubî, el-Câmi, $13 / 77$.

90 Ebû Muhammed İbn Kuteybe, Tefsîru Garîbi'l-Kur'ân, thk. Seyyid Ahmed Sakr (Beyrût: Dâru'l-Kütübi'l-i̇lmiyye, 1978), 254.

91 Zemahşerî, el-Keşşâf, 597.

92 İsfahânî, el-Müfredât, 486.

93 Zemahşerî, el-Keşşâf, 1035; Nesefî, Medârik, 3/351.

94 Sirâcuddîn, Havle, 71. 
azabı çekmesine neden olur. ${ }^{95}$ Âyete "Ey iman edenler" şeklinde başlanılması da bu hususiyete vurgu yapmak için olmalıdır. İnsanlar, "Yapmakta olduğunuz şeylerden mutlaka sorguya çekileceksiniz." âyetinin bir gereği olarak gerek gerçek hayatta gerekse sanal ortamlarda yapıp ettiklerinden mutlaka hesaba çekileceklerdir. Ayrıca Hz. Peygamberimizin "Kişiye günah olarak her duyduğunu söylemesi yeter." ${ }^{\prime 7}$ hadisi sosyal medyada rastlanılan her haberin araştırılmadan paylaşılmasını da kapsamaktadır. Müslümanların bu ve benzeri âyet ve hadislere uygun hareket etmedikleri takdirde pişman olacakları haber verilmektedir.

Sosyal medyada yaptığı paylaşım nedeniyle pişman olan kişilere örnek olarak "07 AN 0054 plakalı kırmızı otobüsün şoförü" başlığıyla facebook platformunda paylaşım yapan bir kullanıcı gösterilebilir. Bu kişi, paylaşımında kızının ağlayarak eve geldiğini ve belediye otobüs şoförünün bir kadına "Eve gidiyorum gelecek misin?" diyerek taciz ettiğini söylediğini yazmış ve yetkililerden konunun gereğinin yapılmasını istemiştir. Fakat bu paylaşım sosyal medyada hızla yayılmış ve olayı araştıran yetkililer gerçeğin hiç de denildiği gibi olmadığını delilleriyle ortaya koymuşlardır. Sonuçta masum bir kişiyi hedef alan bu paylaşımın sahibi sayfasında yaşadığı pişmanlığı şu sözler ile aktarmıştır: "İşin aslının hiç de öyle olmadığını kamera kayıtlarından gördüm. Böyle bir utanç yaşamadığımı düşündüm o an ve kahroldum... Bu yanlışa sebep olduğum için kahroluyorum ve tekrar tekrar özür diliyorum, diliyorum, diliyorum..." ${ }^{98}$

\section{Sonuç}

Sanal ortamlardan sosyal medya platformları, gerçekdışı haberlerin oldukça sık üretildiği ve paylaşıma sokulduğu mecralardır. Bilinçli veya bilinçsiz paylaşıma sokulan bu haberler nedeniyle birçok masum insan zarar görebilmektedir. Sosyal medya kullanıcısının birkaç saniye içinde beğenip paylaştı̆̆ı, altına yorumlar yazdığı bir ileti belki de dakikalar içinde bir kişinin hayatını karartabilmektedir. Yapılan bu sorumsuzca davranışın, müslümanlar nezdinde zulüm kavramı çerçevesinde değerlendirilmesi gereken bir mesuliyet olduğu gayet açıktır. Çünkü sosyal medyada kişisel olarak kullanıcının kendi takipçileriyle paylaştığı gerçekdışı bir haberin internetteki hızlı dolaşım nedeniyle kısa bir zaman zarfında toplumsal bir gündeme dönüşebildiği ve bu durumun muhatap kişiye maddî veya manevî zararlar verebildiği görülmektedir.

Hucurât sûresinin 6 âyetinde müslümanlara, fâsık bir kişinin haber getirmesi halinde acele etmeyerek haberin doğruluğunu araştırmaları emredilmiştir. Günümüz sosyal medya platformlarında sahte kullanıcı hesaplarından veya dinî ve ahlâkî hassasiyet açısından tanınmayan kişilere ait hesaplardan yapılan paylaşımların gerçekdışı olma ihtimali her zaman vardır. Bu

95 Muhammed Hamdi Yazır, Hak Dini Kuran Dili (İstanbul: Eser Neşriyat, 1979), 6/4457.

96 en-Nahl 16/93; Ayrıca bk. el-Hicr 15/92; el-Enbiyâ 21/23; es-Saffât 37/24.

97 Ebû Dâvût, "Edeb”, 80.

98 https://www.facebook.com/huseyin.turan.18/posts/1044954608957696?pnref=story (Erişim Tarihi: 08.05.2021). 
Yıldız, Hucurât Sûresinin 6. Âyeti Bağlamında Sosyal Medyadaki Gerçekdışı Haberler

durumda bir müslümanın, ilgili âyetin hükmü gereği üçüncü şahıslara maddî veya manevî zarar verebilecek paylaşımları beğenme, yayma ve üzerinde yorum yapma hakkı yoktur. Özellikle ilgili âyette geçen fâsı ve nebe' (haber) kelimelerinin nekra olarak kullanılması çok dikkat çekicidir. Çünkü Arapçada nekra kelimeler umum ifade eder. Bu durumda, bu kelimelerin anlam alanlarının sosyal medyadaki kullanıcıları ve yaptıkları paylaşımları da içine alacak şekilde geniş olduğu görülecektir.

Gerçek hayatta dinî vecibelerini yerine getirmeyen ve güvenilirliği konusunda ciddi şüpheler bulunan tanıdık birinin getirdiği haberler ve sosyal medya paylaşımları da ilgili âyetin kapsamına girmektedir. Bu durumda hiç tanımadığımız hatta ahlâkî ve dinî hassasiyetini isim, din, ırk, cinsiyet gibi gerçek kimliğine ait hiçbir şey bilemediğimiz kişilerin verdikleri haberler evleviyetle bu âyetin kapsamına girmektedir. Aynı zamanda sosyal medyadaki haberlere güvenilir kaynaklarca doğrulanmadıkça inanmak, onları paylaşmak ve böylece başkalarına maddî ya da manevî zarar vermek kul hakkına girmektedir. Dolayısıyla meçhul veya güvenilmez birisinden gelen haberin araştırılması yani haberin başka kaynaklarca da doğrulanması gerekmektedir. Çünkü günümüzde her türlü haberleşmenin sanal ortamlara doğru hızlıca kaydığı düşünülürse bu ortamlarda bulunan müslümanların gerçek hayatta olduğu gibi buralarda da dinî ve ahlâkî kurallara riayet etmesi gerekir. Aynı zamanda aşırı bilgi kirliliğinin olduğu internet ortamlarında olayların ve haberlerin gerçek yüzünü görebilmek için eleştirel bir çaba gösterilmesi de gerekmektedir. Bu, belki zahmetli olabilir ama buna katlanmayan kişiler, özellikle sosyal medyada zalimi mazlum, sahtekârı dürüst, suçluyu masum -veya tam tersi- olarak görebilirler. Bu durumda ise âyetin sonunda ifade edilen nedamet ile yüzleşmek kaçınılmaz olacaktır.

Sanal âlem, hiç kimseye sonsuz ve sorumsuz bir özgürlük sahası sunmaz ve de sunmamalıdır. "Ben özgürüm ve bana hiç kimse karışamaz" anlayışı, özellikle sanal âlem söz konusu olduğunda oldukça abartılmaktadır. Gerçek hayatta toplumun huzurunu her ne sebeple olsun bozanlara, başkalarının haklarına zarar verenlere bir yaptırım varsa, sanal ortamlarda da bunu yapanlara bir yaptırım elbette olmalıdır. Devletin ilgili kurumlarının yaptırımları olmakla birlikte bir müslüman için asıl yaptırım ahiret günü vereceği hesabı düşünmek olmalıdır. Çalışmamızda ele aldığımız Hucurât suresinin 6. âyeti, söz konusu sanal ortamlarda işlenebilecek günahlardan biri hakkında müslümanları uyarmakta ve yol göstermektedir.

\section{Kaynakça}

Adevî, Mustafa. et-Teshîl li te’vili't-tenzîl Tefsîru sûreti'l-Hucurât. Cidde: Dâru Mâcid Asîrî, 2000.

Akbaş, Bahattin. “Sanal Ortam ve Mahremiyet”. Diyanet Aylk Dergi 287 (2014), 48-50. 
Yuldız, Unreal News on Social Media in the Context of Verse 6 of Surah Hujurat

Akpınar, M. Raşit. "İslam Hukuku Açısından Sosyal Medya”. Süleyman Demirel Üniversitesi Sosyal Bilimler Enstitüsü Dergisi 28 (2017), 493-509.

Âşıkkutlu, Emin. "Meçhul". Türkiye Diyanet Vakfi İslâm Ansiklopedisi. 28/286-288. Ankara: TDV Yayınları, 2003.

Ayten, Ali. Mutluluğun Peşinde. İstanbul: Çamlıca Yayınları, 2. Baskı, 2018.

Babacan, Mehmet Emin. Sosyal Medya ve Gençlik. İstanbul: Bir Yayıncılık, 2017.

Bayraktutan, Günseli - Binark, Mutlu. Ayın Karanlık Yüzü: Yeni Medya ve Etik. İstanbul: Kalkedon Yayınları, 2013.

Beyânûnî, Abdülmecîd. el-Beyyinâtü fî tefsîri sûreti'l-Hucurât. Cidde: Dâru Nûri'l-Mektebât, 1997.

Beyzâvî, Kâdî. Envârü't-tenzîl ve esrârü't-te’vîl. thk. Subhî Hallâk - Mahmud Atraş. 3 Cilt. Beyrût: Dâru'rReşîd, 2000.

Bolat, Emrah - Macit, Yunus. "Postmodern Şiddet: Siber Zorbalık". Sosyal Medya ve Etkileri. ed. Halil Özcan Özdemir. Ankara: Gece Akademi, 2019.

Bostanc1, Mustafa. Sosyal Medya -Dün Bugün Yarın-. Konya: Palet Yayınları, 2019.

Bursevî, İsmail Hakkı. Rûhu'l-beyân fí tefsîri'l-Kur'ân. 10 Cilt. İstanbul: Matbaa-i Osmâniyye, 1911.

Cereci, Sedat. "İslam Ahlakı Bağlamında Müslümanların Modern Dünyada Teknolojiyle İlişkileri: Sosyal Medyanın Hükmü”. Modernleşme Sürecinde Müslümanlar. ed. Necmettin Çalışkan. Ankara: Nobel Akademik Yayıncılık, 2018.

Cereci, Sedat. Sosyal Medya -Çağlar, Ağlar, Bă̆lar-. İstanbul: Onto Yayınları, 2019.

Cevherî, İsmâil b. Hammâd. es-Sihâh. tah. Ahmed Abdulgafûr Attâr. 7 Cilt. Beyrut: Dârü'l-i̇lm li'lmelâyîn, 1990.

Cevziyye, İbn Kayyım. Bedâi'ut-Tefsîr. thk. Seyyid Muhammed - Sâlih Ahmed. 3 Cilt. Riyad: Dâru İbn Cevzîyye, 1427.

Deligöz, Eda. Sanal Dünya ve İnsan. İstanbul: KDY Yayınc1lık, 2020.

Demirci, Muhsin. Kur'ân Tefsirinde Farklı Yorumlar. 3 Cilt. İstanbul: İFAV Yayınları, 2017.

Demirdaş, Burhan - Kurtulan, Ali Emrah. “Sosyal Medyanın Toplumsal ve İş Ahlakı Üzerine Etkileri”. Sosyal Medya ve Etkileri. ed. Halil Özcan Özdemir. Ankara: Gece Akademi, 2019. 
Yıldız, Hucurât Sûresinin 6. Âyeti Bağlamında Sosyal Medyadaki Gerçekdışı Haberler

Dereli, Mustafa Derviş. Sanala Veda Sosyal Medya ve Dönüşen Dindarlk. Ankara: Nobel Akademik Yayıncllık, 2020.

Dikeçligil, Fatma Belgü. “Ailede Çözülme ve Sosyal Medya Etkisi”. Mahremiyet Bağlamında Sosyal Medya ve Aile. ed. Fatih Kurt. Ankara: DíB Yayınları, 4. Baskı, 2020.

Duman, Mehmet Zeki. Beş Surenin Tefsiri. Ankara: Fecr Yayınları, 1999.

Ebüssuûd Efendi. Irsşâdü'l-akli's-selîm ilâmezâya'l-Kitâbi'l-Kerîm. 9 Cilt. Beyrût: Dâru Ihyâi't-Türâsi'l-Arabî, ts.

Eren, Cüneyt. "Hucurât Suresindeki Ahlâkîîlkeler”. Bozok Üniversitesi İlahiyat Fakültesi Dergisi 3/3 (2016), $1-20$.

Ferâhîdî, Halîl b. Ahmed. Kitâbü'l-Ayn Müratteben alâ hurûfi'l-mu'cem. thk. Abdülhamid Hendâvî. 4 Cilt. Beyrût: Dâru'l-Kütübi'l-İlmiyye, 2003.

Geçer, Ekmel. Sosyal Medya ve İletişim Psikolojisi. İzmir: DİB Yayınları, 2. Baskım, 2020.

Gültekin, Mücahit. Algı Yönetimi ve Manipülasyon -Kanmanın ve Kandırmanın Psikolojisi-. İstanbul: Pınar Yayınları, 6. Baskı, 2018.

Halebî, Ebü'l-Abbâs Semîn. Umdetü'l-huffâz fí tefsîri eşrefi'l-elfâz. thk. Muhammed Bâsıl. 4 Cilt. Beyrût: Mektebetü Dâri'l-İlmiyye, 1996.

Işık, Emin. "Hucurât Sûresi”. Türkiye Diyanet Vakfi İslâm Ansiklopedisi. 18/279. İstanbul: TDV Yayınları, 1998.

İbn Kesîr, Ebü'l-Fidâ'. Tefsî̀ü'l-Kur'âni'l-‘azîm. thk. Sâmi b. Muhammed es-Selîme. 8 Cilt. Riyad: Dâru Tayyibe, 2. Baskı, 1999.

İbn Kuteybe, Ebû Muhammed. Tefsîru Garîbi'l-Kur'ân. thk. Seyyid Ahmed Sakr. Beyrût: Dâru'lKütübi'l-îlmiyye, 1978.

İbn Manzûr, Cemâleddin. Lisânü'l-Arab. 15 Cilt. Beyrut: Dâru Sâdır, ts.

İsfahânî, Râgıb. el-Müfredât fi garîbi'l-Kur'ân. thk. Muhammed Seyyid Keylânî. Beyrut: Dâru'l-Ma'rife, ts.

Karaman, Hayrettin v.dğr. Kur’an Yolu Türkçe Meal ve Tefsir. Ankara: Diyanet İşleri Başkanlığı, 4. Baskı, 2012. 
Ylldiz, Unreal News on Social Media in the Context of Verse 6 of Surah Hujurat

Kesler, Muhammed Fatih. Kur'an-ı Kerim'e Göre Doğru Düşüncenin Engelleri. Ankara: Akçă̆ Yayınları, 2015.

Kıranşal, Abdülaziz. Gençler İçin Sosyal Medya İlmihali. MGV Yayınları, 12. Baskı, 2020.

Kırık, Ali Murat. “Gelişen Web Teknolojileri ve Sosyal Medya Bağımlılı̆̆ı”. Sosyalleşen Birey \& Sosyal Medya Araştırmaları-1. ed. Ali Büyükarslan - Ali Murat Kırık. Konya: Çizgi Kitabevi, 2013.

Kurtubî, Ebû Abdullâh. el-Câmi'li-ahkâmi'l-Kur'ân. thk. Abdullah et-Türkî. Beyrût: Müessesetü'l-Risâle, 2006.

Küçük, Olgun - Koçak, Mevlüt Can. “Internet ve Sosyal Medya Haberlerinde Ötekinin (Suriyeli Sı̆̆ınmacılar) Konumlandırılışı: Konya Örneği”. Journal of Humanities and Tourism Research 10/2 (2020), 275-288.

Mâtürîdî, Ebû Mansûr. Te’vîlâtü Ehli's-sünne. thk. Mecdi Ba Sellum. Beyrût: Dâru'l-Kütübi'l-İlmiyye, 2005.

Mâverdî, Ebü'l-Hasen. en-Nüket ve'l-uyûn. thk. es-Seyyid Abdülmaksûd. 6 Cilt. Beyrût: Dâru'l-Kütübi'lİlmiyye, ts.

Mavnacıoğlu, Korhan. “İnternette Kullanıcıların Oluşturduğu ve Dağıttığı İçeriklerin Etik Açıdan İncelenmesi: Sosyal Medya Örnekleri”. Medya ve Etik Sempozyumu. ed. Mustafa Yağbasan. Elazı̆̆: Fırat Üniversitesi İletişim Fakültesi, 2009.

Mukâtil b. Süleymân. et-Tefsîru'l-kebîr. thk. Abdullah Mahmûd Şehhâte. 4 Cilt. y.y.: Merkezu Tahkîki'tTürâs, 1979.

Nesefî, Ebü’l-Berekât. Medârikü't-tenzîl ve hakâiku't-te'vîl. thk. Yusuf Ali Bedevî. 3 Cilt. Beyrût: Dâru'lKelimi't-Tayyib, 1998.

Okur, Kâşif Hamdi. "Sosyal Medya ve Hak Bilinci”. Mahremiyet Bağlamında Sosyal Medya ve Aile. ed. Fatih Kurt. Ankara: Diyanet İşleri Başkanlı̆̆ı Yayınları, 4. Baskı, 2020.

Özdemir, Vahit. “Yeni Medyada Etik Sorunsalı”. Sosyal Medya ve Etkileri. ed. Halil Özcan Özdemir. Ankara: Gece Akademi, 2019.

Öztürk, Şerife. “Sosyal Medyada Etik Sorunu”. Selçuk İletişim 9/1 (2015), 287-311.

Râzî, Fahreddîn. Mefâtîhu'l-gayb. 32 Cilt. Beyrût: Dâru'l-Fikr, 1981.

Sâbûnî, Muhammed Ali. Ravâ'i'u'l-Beyân fî Tefsîri Âyâti'l-Ahkâm. Dımeşk: Mektebetu'l-Gazzâlî, 3. Basım, 1980. 
Yıldız, Hucurât Sûresinin 6. Âyeti Bağlamında Sosyal Medyadaki Gerçekdışı Haberler

Sayımer, İdil. Sanal Ortamda Halkla İlişkiler. İstanbul: Beta Yayıncllık, 2008.

Sirâcuddîn, Abdullah. Havle tefsîrü sûreti'l-Hucurât. Haleb: Mektebetü Dâri'l-Fellâh, 1992.

Süyûtî, Ebü'l-Fazl Celaleddin. Lübâbü’n-nukûl fî esbâbi'n-nuzûl. Beyrût: Müessesetü'l-Kütübi'sSekâfiyye, 2002.

Şimşek, Mehmet Sait. Hayat Kaynağı Kur’an Tefsiri. 5 Cilt. İstanbul: Beyan Yayınları, 2012.

Taberî, Ebû Ca'fer. Câmi'u'l-beyân an te’vîli âyi'l-Kur'ân. thk. Abdulmuhsîn et-Turkî. 26 Cilt. Kahire: Dâru Hicr, 2001.

Tarhan, Nevzat - Nurmedov, Serdar. Bağımllık Sanal veya Gerçek Bağımlllkkla Başa Çıkma. İstanbul: Timaş Yayınları, 8. Baskı, 2020.

Toktay, Yakup - Kırık, Ali Murat. “Sosyal Medyada Dezenformasyon, Manipülasyon ve Propaganda Etkisi: Zeytin Dalı Harekâtı Örneği”. Sosyal, Beşeri ve İdari Bilimler Alanında Akademik Çalışmalar-2. ed. Hasan Babacan. Ankara: Gece Kitaplığı, 2020.

Tuncer, A. Selim. “Sosyal Medyanın Gelişimi”. Sosyal Medya. ed. F. Zeynep Özata. Eskişehir: Anadolu Üniversitesi Yayınları, 2013.

Vâhidî, Ebü'l-Hasen. Esbâbü’n-nüzûl. thk. Kemal Besyûnî Zağlûl. Beyrût: Dâru'l-Kütüb'i-İlmiyye, 1991.

Yağır, Mehmet Yusuf. "Günümüz Medyasının Hucurât Suresindeki Bazı Ahlaki İlkelere Göre Değerlendirilmesi”. şarkiyat 10/2 (2018), 638-650.

Yazır, Muhammed Hamdi. Hak Dini Kuran Dili. İstanbul: Eser Neşriyat, 3. Baskı, 1979.

Yıldız, İbrahim. Kur'ân İnsan ve Yanılgı-Psikososyal Bir Okuma-. Bursa: Emin Yayınları, 2019.

Yıldız, İbrahim. “Kur’ân’da Hesap Günü Şahitleri”. Diyanet İlmi Dergi 53/4 (2017), 55-75.

Yılmaz, Musa Kazım. "Hucurât Suresinin Öne Çıkardığı Âdâb-1 Muâşeret". Harran Üniversitesi İlahiyat Fakültesi Dergisi 38 (2017), 1-30.

Zemahşerî, Ebü'l-Kâsım. el-Keşşâf an hakẩikı gavâmizi't-tenzîl ve uyûni'l-ekâvîl fî vücûhi't-te'vîl. thk. Halil Me'mun Şeyha. Beyrut: Dâru'l-Ma'rife, 2005. 
Unreal News on Social Media in the Context of Verse 6 of Surah Hujurat

\author{
Assistant Professor İbrahim Yıldız
}

\title{
Extended Summary
}

In the 21st century, people live in the internet age. In this age, means of receiving news, interpersonal relations, and even people's reaction to each other have been transferred to virtual environments. Today, social media significantly meets the communication and news needs of its users. There are doubts about the real identities of the users due to the fact that social media user profiles allow for the change of identity. This situation raises doubts about whether the content created or shared on social media is real or not.

In addition, these virtual environments allow their users to develop an attitude that they can act freely, escape from responsibility and will not be responsible for what they do, since they allow identity change and use of false identities. This thought is not an acceptable thought for a Muslim who believes that he will be held accountable in the hereafter. Since a Muslim believes that he will be accountable for all his behaviors and actions, he must know that this account will include what he does in virtual environments and behave accordingly. Therefore, it is a requirement of a Muslim's faith to continue the responsibilities of a Muslim under his virtual identity and to comply with these values in virtual environments as well.

Social media platforms from virtual environments are the channels where unreal news is produced and shared quite frequently. Many innocent people can be harmed by these news that are shared consciously or unconsciously. A message that a social media user likes and shares in a few seconds, writes comments under it, may darken a person's life within minutes. It is clear that this irresponsible behavior is a liability that should be evaluated within the framework of the concept of cruelty for Muslims. Because it is a fact that an unreal news that the user personally shares with his followers on social media can turn into a social agenda in a short time due to the rapid circulation on the internet and this situation can cause material and moral damages to the addressee.

Considering that all kinds of communication are rapidly shifting towards virtual environments today, Muslims in these environments should obey religious and moral rules in these environments as in real life. "O ye who believe! If a wicked person comes to you with any news, ascertain the truth, lest ye harm people unwittingly, and afterwards become full of repentance for what ye have done." the verse also covers the unreal news sharing on social media. It is within the scope of this verse 
Yıldız, Hucurât Sûresinin 6. Âyeti Bağlamında Sosyal Medyadaki Gerçekdışı Haberler

that the news that target some people and groups on social media, denigrate, humiliate and accuse them, immediately approves without being investigated, making a hasty decision, and making various accusations against them.

Unless the news received on social media are verified by reliable sources, it is also the right of people to believe in them, share them and thus cause material and moral harm to others. Therefore, investigating the news coming from an unknown or untrustworthy person and confirming the news by other sources with the language of the media should be one of the basic moral principles of Muslims. Because today, a critical effort is required to see the real face of events and news. This may be troublesome, but people who do not take it, especially on social media, can view the cruel as the oppressed, the honest thief, the criminal as the innocent.

Spreading unreal news on social media poses a problem in two ways. The first is to be put in a criminal situation due to the individual victimization caused by spreading this false news. The second is the situation that causes the society to become uncomfortable with an untrue news and to create hatred towards someone in the society. Therefore, those who cause harm to innocent people by producing fake news on social media platforms, knowingly or unknowingly, commit crimes in an open and uncontested manner.

The relevant verse of the Surah Hucurat that we discussed in our study warns and guides Muslims for one of the major sins that can be done in these virtual environments. In the 6th verse of the chapter of Hucurat, when a fasiq brings the news, it is ordered to investigate the news thoroughly in order not to harm people. Social media users whose religious and moral situations are unknown are not directly considered as a fasiq. However, it is certain that at least these people are anonymous people who are likely to a fasiq. For this reason, there is no doubt that the news they reported are also within the scope of the relevant verse. The fact that Muslims cause innocent people to suffer material and moral damage by liking, sharing or commenting on unreal news on social media platforms requires religious responsibility. In this study, social media, opening fake user accounts, producing, spreading false news and their religious responsibility were investigated in detail in the context of the 6th verse of the chapter of Hucurat.

Keywords: Commentary, Surah Hucurat, Social Media, Fake Account, Deepface, Manipulation. 
